\title{
Development Strategy of Indonesian Palm Oil Industrial Cluster Based International Trade Connectivity
}

\author{
Sapta Raharja ${ }^{1 *}$, Setiadi Djohar ${ }^{2}$, Dwi Aryanthi ${ }^{1}$ \\ ${ }^{1}$ IPB University, Bogor 16680, Indonesia \\ ${ }^{2}$ College of Management PPM, Jakarta 10340, Indonesia
}

\begin{abstract}
Indonesia is the largest producer and the exporter of palm oil in the world which has three palm oil industrial cluster (POIC) areas that are Sei Mangkei (North Sumatera), Dumai (Riau), and Maloy (East Kalimantan). To carry out the delivery of palm oil products to the destination countries, the Palm oil from the three POICs must be transshipment in Malaysia and Singapore. In line with this issues, a strategy to develop the POIC based international connectivity need to be done. This study aims to identify the actual conditions of POIC Indonesia, to determine the factors (internal and external) that influence the development of POIC, and to formulate priority strategy for developing POIC Indonesia. These are needed so that Indonesia can become a hub port of international trade especially in Asia. This research uses "Diamonds" Porter's Model, gap analysis, and the Analytical Hierarchy Process (AHP). Based on the analysis connectivity, the main strategy that can be formulated in order to develop Indonesian palm oil industry cluster is infrastructure improvements. This strategy can be done if the government (the Ministry of economy, Ministry of industry and trade, Ministry of sea, PT PELINDO, and local government), private sector, academic, and the public is able to work together and integrated.
\end{abstract}

Key words: AHP, "Diamonds" Porter's Model, gap analysis, palm oil industrial cluster

\section{INTRODUCTION}

Indonesia is the largest producer and exporter of palm oil in the world. Oil palm plantations in Indonesia in 2018 reached 14.3 million hectares and In 2020 Indonesia's crude palm oil (CPO) production rose from 46 million tons to 49 million tons or grew $6.1 \%$, with the amount of production Indonesia is still the largest palm oil producer and controls $48 \%$ of the world market share (Wiryawan 2013, Crop Estate Statistic 2019). The export value of palm oil in 2011 reached

\section{${ }^{*}$ Corresponding author:}

Department of Agro-Industrial Engineering, Faculty of Agricultural Engineering and Technology, IPB University, Bogor 16680, Indonesia.

E-mail: saptaraharja@apps.ipb.ac.id. 
US \$ 16.2 billion for CPO products and US $\$ 1.55$ billion for palm kernel oil (PKO) products. The large export value of Indonesian palm oil to the international market shows the important role of the palm oil industry in Indonesia's economy.

The development of the oil palm industry through the ordering and building industrial clusters following the Decree of the Minister of Industry (KMP No.13/MIND/PER/I/2010) which has designated three areas as locations for the establishment of the oil palm industrial cluster (POIC), namely Sei Mangkei (North Sumatra), Dumai and Kuala Enok (Riau), and Maloy (East Kalimantan). The three regions are currently not well connected to the domestic market and the international market. So, to make a shipment, a transshipment must be carried out which causes Indonesian palm oil products to be unable to compete with Malaysian palm oil products, especially for downstream palm oil products. This is not in line with the concept of industrial clusters that will be formed by the government, where industrial clusters can be defined as geographic concentrations of related industries and their integrated institutions (JICA 2004).

The connectivity in the three areas of POIC Indonesia which has not been developed has made the competitiveness of Indonesian palm oil products not yet strong. Several things that need to be considered in the development of industrial clusters include identification and mapping of the characteristics and connectivity of the cluster area with other regions, creating a conducive climate through improving government policies, stakeholder cooperation, and providing supporting facilities and institutions cluster (Gumbira Said et al. 2012).
Based on this, a strategy is needed to develop an Indonesian palm oil industry cluster based on international trade. The objectives of this study include identifying the actual conditions of Indonesia's POIC (Sei Mangkei, Dumai - Pelintung, and Maloy), determining external and internal factors that influence the development of Indonesian POIC, and recommending appropriate strategic priorities for developing Indonesian POIC so that Indonesia can become the entrance to the world oil palm trade, especially Asia.

\section{MATERIALS AND METHODS}

This research was conducted within eight months which took place in Bogor, Jakarta, North Sumatra, and East Kalimantan. The sampling technique used in this study was non-probability sampling. Determination of respondents intentionally (purposive sampling) through the approach of expertise judgment (Cooper \& Schindler 2006). This technique is used because the selected respondents are experts who have the capacity and ability to formulate a development strategy for POIC Indonesia. The research involved several stakeholders in the development of oil palm industry clusters, namely: Indonesian Palm Oil Society (MAKSI), Indonesian Palm Oil Council (DMSI), Indonesian Palm Oil Entrepreneurs Association (GAPKI), Business Actors, Academics, Local Government.

This study uses two types of data, namely primary and secondary data. Primary data obtained from structured interviews using a questionnaire to experts as respondents. Secondary data were obtained from various sources through library studies, agencies, and other institutions as well as internet 
references. The technique of collecting data and information in this study was carried out by means of observation, interviews, and literature study.

Data analysis uses the Berlian Porter model to analyze the internal and external environment of POIC Indonesia. Porter's Diamond Model is a competitiveness model to describe the competitiveness of a country (region) which consists of input factor conditions, demand factor conditions, competition conditions in the context of corporate (state) strategy and rivalry, as well as related supporting industries to produce competitive advantages in the form of power. competitiveness of industrial clusters as a derivative of the gem model (Snowdown \& Stonehouse 2006).

Analysis of the internal and external environment using the Berlian Porter model will produce a picture of the actual conditions in POIC Indonesia. After that, it is followed by a gap analysis to get an overview of the actual and expected conditions. The gap analysis used as a benchmark is the Lahad Datu Palm Oil Industrial Cluster (POIC). After that, the strategy will be formulated using the Analytical Hierarchy Process (AHP). AHP is a measurement theory using a quantitative approach and/or intangible criteria (Saaty, 2000). Decision-making is done with a multicriteria approach through pairwise comparisons that come from a preference scale among a group of alternatives (Saaty 2000).

\section{RESULTS AND DISCUSSION}

Analysis of the internal and external environment of POIC Indonesia is analyzed using Porter's Diamond Model which is shown in Figure 1. The Porter-Diamond Model used was adopted from the
Oil Palm Industry Cluster Model (Pratiwi 2011).

Based on the results of the analysis of the internal and external environment, the actual cluster conditions are shown in Table 1. Form this analysis it shown that the readiness of POIC in terms of plantation land is quite good, but it needs improvement in the element derivative product. Infrastructure of land transportation, ports and other facilities is classified as need to be improved.

Gap analysis was carried out using the elements obtained in the POIC internal and external environmental analysis. In this analysis, POIC Lahad Datu, Malaysia is used as a benchmark as a reference for ideal industrial cluster conditions. The grouping of the condition scores for the elements is very poor with one (1), bad for two (2), good for three (3), and for very good for four (4). The results of the analysis are shown in Figure 2 and Figure 3. The result of study shown that internal and external facrors which are classified as good are area plantation and synergy between central and local government. The others factors neet to be improved especially port and facilities that classifies as poor. Pahan (2011) said that development of industrial cluster performance were need strong foundation of bussiness and economic environment competitiveness that manifested on supporting infrastructure upgrading. This activity would support supply chain facility integration and network externality.

Analytical hierarchy process was used to formulate the strategy of development of palm oil industry clusters in Indonesia based on connectivity. This methode was used in the development of palm oil industry clusters in the East Kalimantan (Monayo 2013) and development strategy of managing special economic zone 


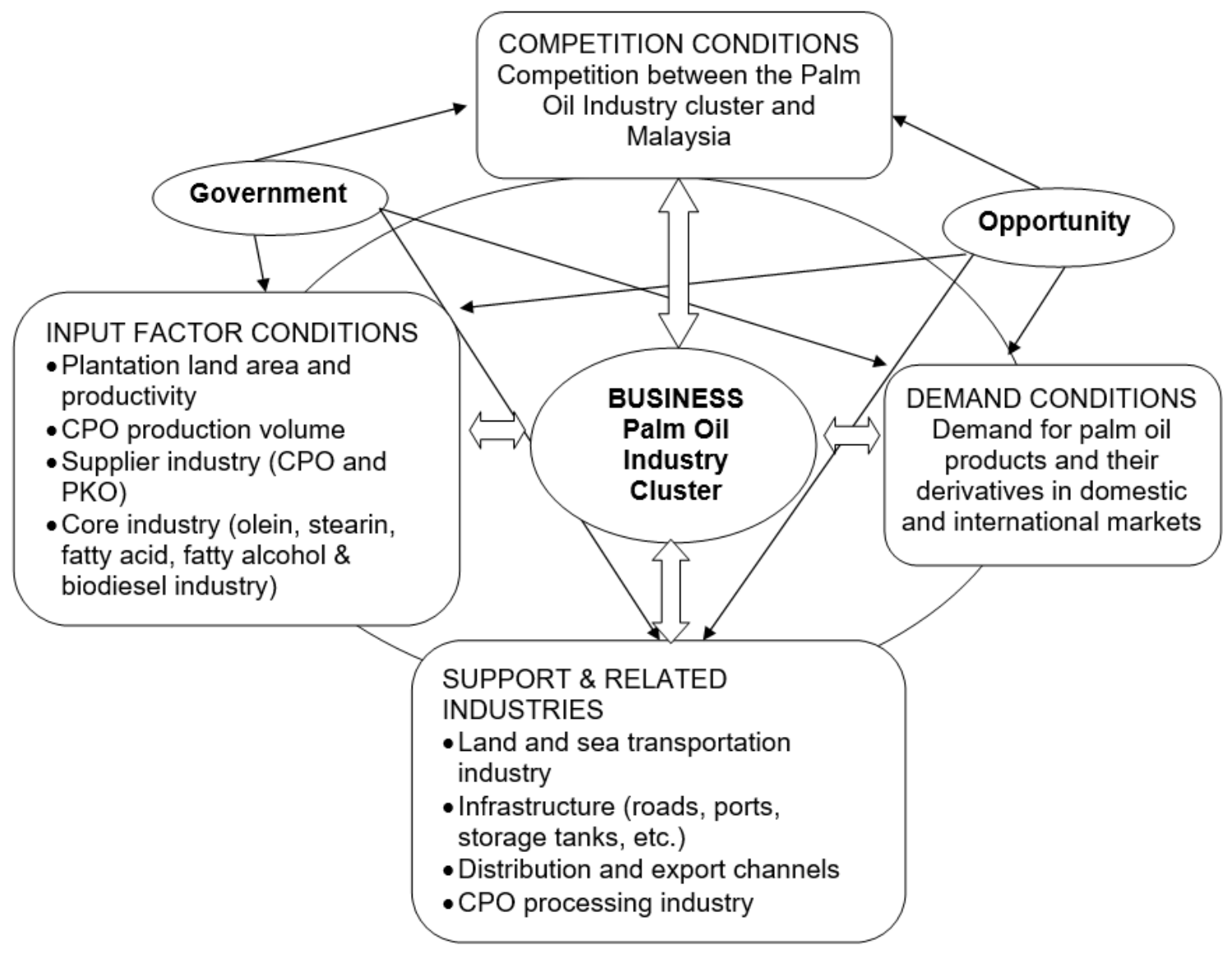

Figure 1 The Indonesian palm oil industrial cluster porter diamond model.

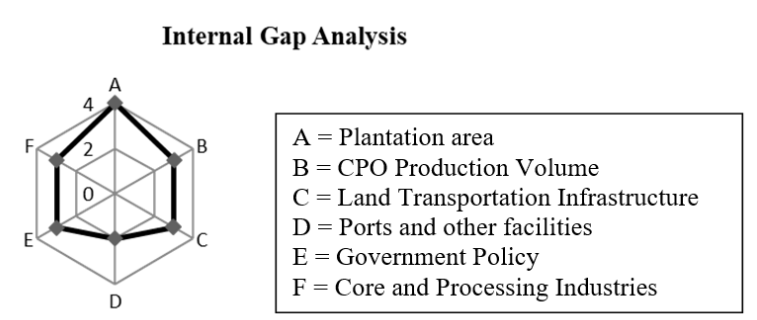

Figure 2 Gap analysis of the internal elements of $\mathrm{POIC}$ in Indonesia.

A External Gap Analysis

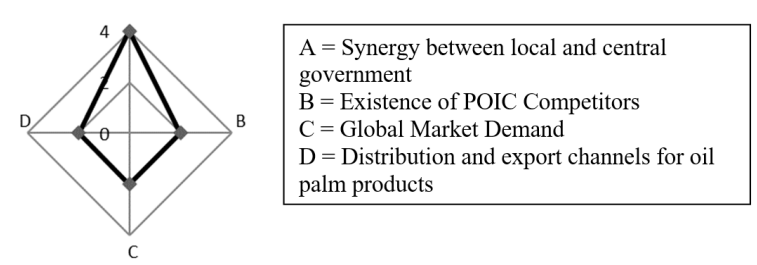

Figure 3 Gap analysis of the external elements of $\mathrm{POIC}$ in Indonesia.
Sei Mangke based industrial cluster and integrated (Febriano et al. 2017).

The results of selecting the priority cluster development for the oil palm industry in Indonesia were carried out using the analytical hierarchy process (AHP) method as shown in Figure 4. Based on the results of the analysis using the hierarchy process, there are several things that need to be done by the government, the private sector, and academia, including improving regulations, improving infrastructure, and increasing added value through continuous innovation. This result was in accordance with the result of Manayo (2013) that said the priority goal of development strategy of POIC in East Kalimantan (Malay) was strategy alliances with the main goal to increase export of derivated product. 
Table 1 Internal and external elements of POIC Indonesia and POIC Malaysia

\begin{tabular}{|c|c|c|c|c|c|}
\hline \multirow[t]{2}{*}{ No } & \multirow[t]{2}{*}{ Element } & \multicolumn{3}{|c|}{ Indonesia } & \multirow[t]{2}{*}{ Malaysia } \\
\hline & & Sei Mangkei & Dumai & Maloy & \\
\hline 1 & $\begin{array}{l}\text { Plantation } \\
\text { Area }\end{array}$ & $\begin{array}{l}\text { The land area in } 2 \\
8,908,399 \text { hectare }\end{array}$ & 10: $8,110,447$ hecta & res and 2011: & $\begin{array}{l}\text { The land area in } \\
\text { 2010: } 4.58 \text { million } \\
\text { hectares in 2011: } 5 \\
\text { million hectares }\end{array}$ \\
\hline 2 & $\begin{array}{l}\text { Core and } \\
\text { related indus- } \\
\text { tries }\end{array}$ & $\begin{array}{l}\text { Cooking oil in- } \\
\text { dustry, fatty acid, } \\
\text { glycerine, soap } \\
\text { and detergent } \\
\text { industries }\end{array}$ & $\begin{array}{l}\text { The olein, stea- } \\
\text { rin and PFAD } \\
\text { industries, fatty } \\
\text { acid industry, fatty } \\
\text { alcohol industry, } \\
\text { biodiesel industry }\end{array}$ & $\begin{array}{l}\text { Basic oleo- } \\
\text { chemical } \\
\text { industry, food } \\
\text { based industry, } \\
\text { non food indus- } \\
\text { try, supporting } \\
\text { facilities }\end{array}$ & $\begin{array}{l}\text { Industri biodiesel, } \\
\text { refinery, fatty alcohol, } \\
\text { fatty acid, palm kernel } \\
\text { crushing, solvent } \\
\text { extraction plant, fertil- } \\
\text { izer, bioenergy, food, } \\
\text { and biomass, etc }\end{array}$ \\
\hline
\end{tabular}

3 Infrastructure

\begin{tabular}{|c|c|c|c|c|c|}
\hline & $\begin{array}{l}\text { a. Land } \\
\text { transporta- } \\
\text { tion }\end{array}$ & $\begin{array}{l}\text { Road ( } 20 \% \text { heav- } \\
\text { ily and moder- } \\
\text { ately damaged), } \\
\text { railroads are still } \\
\text { under construc- } \\
\text { tion }\end{array}$ & $\begin{array}{l}\text { Railway, and rail } \\
\text { siding } \\
\text { Fly over and } \\
\text { highway }\end{array}$ & $\begin{array}{l}\text { Roads (moder- } \\
\text { ate, minor, and } \\
\text { severe damage } \\
\text { reaches } 90 \% \text { ) }\end{array}$ & $\begin{array}{l}\text { Railway, and rail } \\
\text { siding } \\
\text { Fly over and highway }\end{array}$ \\
\hline & b. Port & $\begin{array}{l}\text { Belawan and } \\
\text { Kuala Tanjung } \\
\text { Road ( } 20 \% \text { heavi- } \\
\text { ly and moderately } \\
\text { damaged) } \\
\text { There is no port } \\
\text { with international } \\
\text { standards }\end{array}$ & $\begin{array}{l}\text { Lahad Datu port, } \\
\text { Kuantan Port }\end{array}$ & $\begin{array}{l}\text { There is no } \\
\text { railroad yet } \\
\text { Maloy }\end{array}$ & \multirow[t]{2}{*}{$\begin{array}{l}\text { Lahad Datu port, } \\
\text { Kuantan Port } \\
\text { International stan- } \\
\text { dards: liquid bulk } \\
\text { terminal, dry bulk } \\
\text { terminal and contain- } \\
\text { er terminal (Asian } \\
\text { trading hub) }\end{array}$} \\
\hline 4 & Connectivity & \multicolumn{3}{|c|}{ Must carry out transhipment to Malaysia and Singapore } & \\
\hline \multirow[t]{3}{*}{5} & \multirow[t]{3}{*}{ Trading } & \multicolumn{3}{|c|}{2011 CPO and PKO exports: US \$ 10.4 billion } & $\begin{array}{l}2011 \text { CPO and PKO } \\
\text { exports: RM 3,219 }\end{array}$ \\
\hline & & \multicolumn{3}{|c|}{2011 export of other products: US \$ 9 billion } & $\begin{array}{l}\text { Export of other prod- } \\
\text { ucts: RM } 80.4 \text { billion }\end{array}$ \\
\hline & & \multicolumn{3}{|c|}{$\begin{array}{l}\text { Destination Countries: India, China, Netherlands, } \\
\text { Bangladesh, Egypt, Singapore, Italy, Spain, Russia, } \\
\text { Ukraine and other countries }\end{array}$} & $\begin{array}{l}\text { Destination countries: } \\
\text { European Union, } \\
\text { Brazil, United Arab } \\
\text { Emirates, America, } \\
\text { China, India, etc (100 } \\
\text { export destination } \\
\text { countries) }\end{array}$ \\
\hline
\end{tabular}




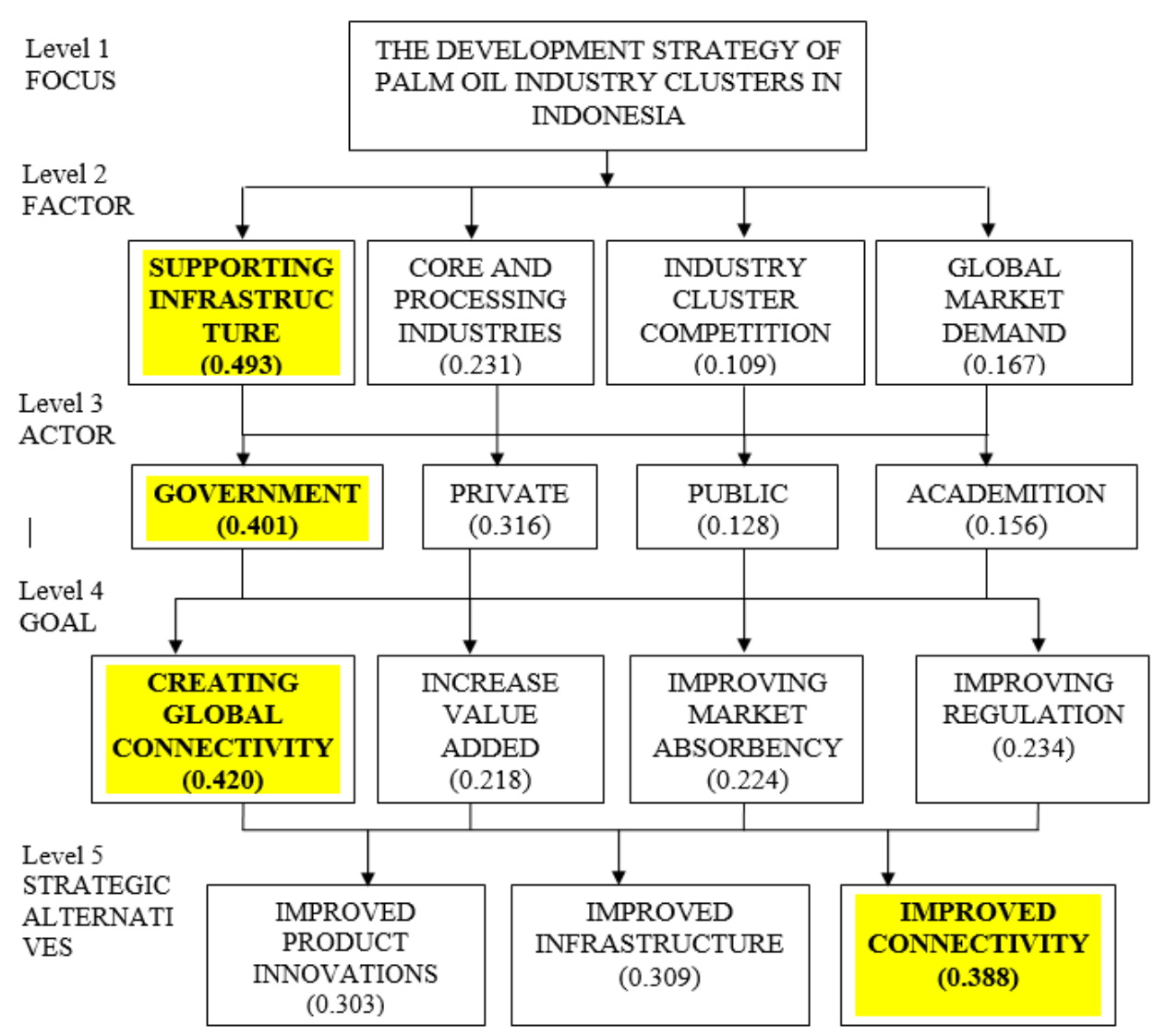

Figure 4 Results of processing priorities for POIC development in Indonesia.

From this, it can be said that improvement connectivity was important to develop POIC in Indonesia. Based on the Febriano et al (2017), institutional strengthening and accelerated development of infrastructure are the crucial factor should be prioritized for the development of palm oil based industrial cluster at Sei Mangkei. This research also indicated that alliances are important. Government must cooperate with private sectors to develop Sei Mangkei POIC. Policy implicaton need was develop and strengthen coordination within sector and cluster (Pahan 2011).

From this research (Figure 4), the government, in this case, the ministry of transportation, the ministry of industry, the ministry of economy, and PT Pelabuhan Indonesia have an important role in improving infrastructure related to improving logistics systems, ports, transportation systems, as well as information and technology. The importance of supporting infrastructure were requisite for successful of industrial cluster and critical for Ministry Industry policy initiatives (Pahan 2011). In addition, to achieve international connectivity, the transportation contract system should be changed from FOB to CIF, so it is hoped that more efficient connectivity is achieved as shown in Figure 5.

\section{CONCLUSIONS}

Based on the results of the analysis of the internal and external environment, several elements influence the development of the Indonesian palm oil industry cluster. Internal elements that influence the development of POIC Indonesia are the area of plantation land, production volume of CPO, land transportation 


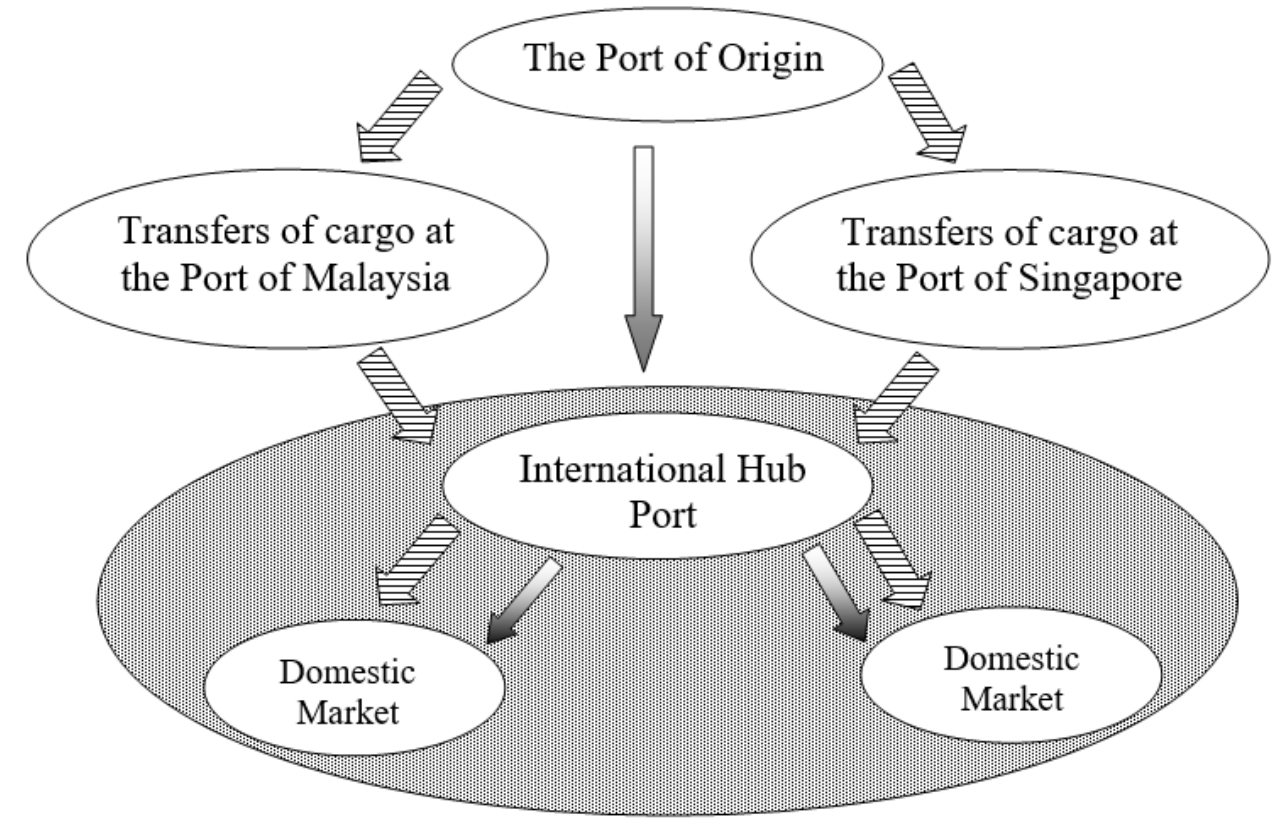

Figure 5 Illustration of product transportation in world trade to Indonesia (Directorate General of Sea Transportation, 2012).

infrastructure, ports and other facilities, government policies, and the core industry and CPO processing. External factors that influence the development of Indonesia's POIC are industrial cluster competitors (Malaysia), product demand, central and regional government synergies, distribution channels and palm oil exports.

Based on the analysis using a hierarchy process, what the government needs to do is improve infrastructure and increase added value through continuous innovation. To achieve international connectivity, the transportation contract system should be changed from FOB to CIF. So, it is hoped that more efficient connectivity is achieved.

\section{RECOMMENDATIONS}

Suggestions for further research are needed to add the factors that influence the development of the oil palm industrial cluster, which is compiled in Porter's "Di- amonds" model. Further research efforts are needed to develop oil palm industrial clusters in each of Indonesia's POIC areas by adjusting developments in the field.

\section{ACKNOWLEDGMENTS}

The authors would like to thank the Indonesian Palm Oil Community (MAKSI), the Association of Indonesian Palm Oil Entrepreneurs (GAPKI), the North Sumatra Industry and Trade Office, PT PELINDO I in the Belawan region, a shippingline company, and PT Bakrie Sumatera Plantation who have helped during data collection.

\section{REFERENCES}

Cooper DR, Schindler PS. 2006. Business research methods Ninth Edition. Boston (US): Mc Graw-Hill.

Febriano MR, Hariyadi, Faroby FA. 2017.

Strategi pengelolaan kawasan ekonomi 
khusus (kek) sei mangke, klaster industri hilir kelapa sawit terintegrasi dan berkelanjutan. Agrica. 10(1):22-35.

Gumbira-Said E, Raharja S, Pahan I, Fahmi QAS, Evalia A, Agustina Y. 2012. Kajian kelengkapan infrastruktur dan jenis industri residen pada klaster industri kelapa sawit indonesia dalam menunjang program MP3EI. In Soesilowati, editors. Integrasi Kebijakan dan Penguatan Industri Naional Menuju Percepatan dan Perluasan Ekonomi Indonesia. Prosiding Seminar Nasional. Semarang: UNNES.p 320 - 337.

Japan International Cooperation Agency (JICA). 2004. Studi Penguatan Kapasitas Klaster UKM di Republik Indonesia [Final Report]. Jakarta (ID): KRRI Internaional Corp.

Manayo AW. 2013. Strategi Pengembangan Klaster Industri Kelapa Sawit di Kalimantan Timur. Bogor (ID): Institut Pertanian Bogor.

Ministry Industry of Republic Indonesia. 2013. Rules No No.13/M-IND/ PER///2010 about Program Restukturisasi Mesin dan atau Peralatan Industri Kecil dan Menengah (IKM). Jakarta (ID) :Ministry of Law and Human Right. State news of Republic Indonesia 2013 No 326.

Pahan I. 2011. Pengembangan klaster industri kelapa sawit di Indonesia. [Disertation]. Bogor (ID): Institut Pertanian Bogor.
Porter ME. 1990. The competitive advantage of nation. Harv Bus. 1990:73-91.

Pratiwi E. 2011. Analisis determinan ekspor CPO Indonesia ke Uni Eropa. Medan (ID): Universitas Sumatera Utara.

Rodriguez-Clare A. 2005. Coordination failures, clusters and microeconomic interventions. Washington DC (US): Research Department, Inter-American Development Bank. Research Network Working Paper R-544.

Saaty TL. 2000. Pengambilan keputusan bagi para pemimpin: proses hirarki analitik untuk pengambilan keputusan dalam situasi yang kompleks [Terjemahan]. Jakarta: Lembaga Pendidikan dan Pembinaan Manajemen (LPPM) dan PT. Pustaka Binaman Pressindo.

Snowdown B, Stonehouse G. 2006. Competitive in globalized world : Michael Porter on the microeconomics foundation of the competitiveness of nation, region, and firms. J Int Buss Stud. 37:163-175.

Tree Crop Estate Statistics of Indonesia 2018-2020. 2019. Kelapa sawit (palm oil). Jakarta (ID): Directorate General of Estate Crops.

Wiryawan G, Anwar R, Sitorus SRP, Fauzi AM, Widiatmaka, Machfud. 2016. Pencapaian standar Indonesia sustainable palm oil (ISPO) dalam pengelolaan perkebukan kelapa sawit di Kalimantan Timur. J Littri. 22(1):11-18. 